Ann. Génét. Sél. anim., 1973, 5 (4), 495-498.

NOTE

\title{
ON METHODS OF ESTIMATION OF MATERNAL HETEROSIS AND RECOMBINATION EFFECTS FROM A SPECIFIC THREE BREEDS CROSSING SYSTEM
}

\author{
R. RASTOGI and C. CHEVALET* \\ Laboratoire de Génétique des Petits Ruminants, \\ * Laboratoire de Génétique Cellulaire, \\ Centre de Recherches de Toulouse, I. N. R. A., \\ B. P. 12, 31320 Castanet Tolosan
}

\section{SUMMARY}

The present note is an extension of Dickerson's (A. B. A., 1969, 19I-202) paper. Three different methods for the estimation of maternal heterosis from a specific 3-breed crossing system were evaluated for possible biases. Method II was found to provide most nearly an unbiased estimate of maternal heterosis $(h \mathbf{M})$. For example,

$$
h_{\mathrm{AB}}^{\mathrm{M}}=\mathrm{C}(\mathrm{AB})+(\mathrm{AC}+\mathrm{BC}) / 2-(\mathrm{AB}) \mathrm{C}-(\mathrm{CA}+\mathrm{CB}) / 2 .
$$

It was further suggested that the same data could be used to estimate epistatic recombination effects.

Dickerson (I969) stated, "Near maximum performance is expected in the best 3-breed cross of superior sire breed with crossbred females of 2 other breeds having the best economic combinations of $F_{1}$ maternal and transmitted performance characteristics ". This will be generally true for those offspring characteristics that are influenced by indirect maternal effects such as, growth. Thus, to maximize and to accurately predict immediate gains from a specific 3-breed crossing system a knowledge of the magnitude of maternal heterosis and epistatic recombination effects is essential.

The present note is an extension of Dickerson's paper and here we briefly review different methods used to estimate maternal heterosis for their merits and limitations. It is further suggested that the same data can also be used to arrive at estimates of epistatic recombination effects. 


\section{DEFINITIONS}

Let mean performance of three breeds be represented by letters A, B and C, respectively. Further assume that all possible pure breeds, 2- and 3-breed crosses are produced contemporaneously. Then,

$h^{\mathbf{I}}=$ individual heterosis and is the mean deviation in the performance of 2 -breed crosses from the average performance of pure breeds due to increased average heterozygosity of $\mathrm{F}_{1} s$, plus any epistatic interaction between purebred parental gametes.

$h^{\mathrm{M}}=$ maternal heterosis and is the same as $h^{\mathrm{I}}$ but for indirect maternal effects of $\mathrm{F}_{1}$ crossbred dams. It is a measure of average dominance interaction deviations in maternal effect $(m)$ of $F_{1}$ dams relative to that of purebred dams, for example

$$
h_{\mathrm{AB}}^{\mathrm{M}}=\left(2 m_{\mathrm{AB}}-m_{\mathrm{AA}}-m_{\mathrm{BB}}\right) / 2
$$

$h^{\mathrm{P}}=$ paternal heterosis and is analogous to $\mathrm{h}^{\mathrm{M}}$ but for indirect paternal effects.

$r^{\mathrm{I}}=$ epistatic recombination effects and is the deviation due to change in epistatic gene interaction effects in 3-breed crosses, relative to those in 2-breed crosses, from recombinations between gametes derived from parent breeds of $F_{1}$ crossbred sires or dams.

The parameters- $h \mathrm{M}, h^{\mathrm{P}}$ and $r^{\mathrm{I}}$ are specific effects of crossbred dam's or sire's genotype but are measured as environmental effects from analyses of offspring data.

\section{EVALUATION OF VARIOUS METHODS}

Various comparisons used to estimate maternal heterosis and epistatic recombination effects have been summarized in the following table along with their genetic expectations. No attempt has been made to explicitely derive these expectations. However, it can be easily accomplished in closely following Dickerson (1969).

To arrive at these expectations and to obtain unbiased estimates certain assumptions must be made ; the critical ones are :

a) linkage equilibrium and randomness of mating.

b) interaction effects involving three or more loci are negligible.

c) additive (no interaction) combination of genetic and heterotic contribution of different breeds in various crosses, for example :

and also

$$
g_{\mathrm{C}(\mathrm{AB})}=\left(2 g_{\mathrm{CC}}+g_{\mathrm{AA}}+g_{\mathrm{BB}}\right) / 4
$$

$$
h_{\mathrm{C}(\mathrm{AB})}^{\mathrm{r}}=\left(h_{\mathrm{CA}}^{\mathrm{I}}+h_{\mathrm{CB}}^{\mathrm{I}}\right) / 2 \text {, }
$$

that is, environmental effect is the same for all breed groups (purebred, 2- and 3-breed cross).

d) no interaction between genetic contribution of the sire and the maternal ability of the dam. Such interaction might arise if a sire gave his offspring genetic growth potential that was incompatible with the milking ability of the dam.

$e)$ no confounding with differences in proportion of multiple births; sex; year, season and date of birth; heterosis in male $\left(h \delta^{*}\right)$ and female ( $h$ o $)$ reproductive performance.

f) $\gamma^{\mathbf{I}}=\mathrm{o}$ (applicable only to method I).

g) $h^{\mathrm{P}}=0$. 
In species like swine, sheep and rabbit, use of individual observations will lead to less precise estimates of $h^{\mathrm{M}}$ due to confounding of differences in proportion of multiple births between crossbred and purebred dams. The estimates of $h^{\mathrm{M}}$ and $r^{\mathrm{I}}$ will be further less precise if $h \sigma^{\star}$ and $h$ ㅇ was of significance. In mathematical sense, these estimates will be unbiased but will not necessarily have minimum variance.

\section{TABLE I}

Various comparisons of interest and their genetic expectations Espérances génétiques des comparaisons de génotypes utilisables pour estimer l'hétérosis maternel $\left(h^{\mathrm{M}}\right)$ et les effets de recombinaison $(r \mathrm{I})$

\begin{tabular}{|c|c|}
\hline Comparison (1) & Genetic expectation \\
\hline \multicolumn{2}{|c|}{ Maternal heterosis $\left(h^{\mathrm{M}}\right)$} \\
\hline Method I & $h^{\mathrm{M}}+1 / 4 r^{\mathrm{I}}$ \\
\hline $\begin{array}{l}\mathrm{A}(\mathrm{BC})-(\mathrm{AB}+\mathrm{AC}) / 2 \\
\mathrm{~B}(\mathrm{AC})-(\mathrm{BA}+\mathrm{BC}) / 2 \\
\mathrm{C}(\mathrm{AB})-(\mathrm{CA}+\mathrm{CB}) / 2\end{array}$ & $\begin{array}{l}h_{\mathrm{BC}}^{\mathrm{M}}+1 / 4 r_{\mathrm{BC}}^{\mathrm{I}} \\
h_{\mathrm{AC}}^{\mathrm{M}}+1 / 4 r_{\mathrm{AC}}^{\mathrm{I}} \\
h_{\mathrm{AB}}^{\mathrm{M}}+1 / 4 r_{\mathrm{AB}}^{\mathrm{I}}\end{array}$ \\
\hline
\end{tabular}

and similarly for reciprocal dams.

\begin{tabular}{c|c}
\hline Method II (Dickerson, 1973) & $h^{\mathrm{M}}-h^{\mathrm{P}}$ \\
\hline $\mathrm{A}(\mathrm{BC})+(\mathrm{BA}+\mathrm{CA}) / 2-(\mathrm{BC}) \mathrm{A}-(\mathrm{AB}+\mathrm{AC}) / 2$ & $h_{\mathrm{BC}}^{\mathrm{M}}-h_{\mathrm{BC}}^{\mathrm{P}}$ \\
$\mathrm{B}(\mathrm{AC})+(\mathrm{AB}+\mathrm{CB}) / 2-(\mathrm{AC}) \mathrm{B}-(\mathrm{BA}+\mathrm{BC}) / 2$ & $h_{\mathrm{AC}}^{\mathrm{M}}-\mathrm{AC}^{\mathrm{AC}}$ \\
$\mathrm{C}(\mathrm{AB})+(\mathrm{AC}+\mathrm{BC}) / 2-(\mathrm{AB}) \mathrm{C}-(\mathrm{CA}+\mathrm{CB}) / 2$ & $h_{\mathrm{AB}}^{\mathrm{M}}-h_{\mathrm{AB}}^{\mathrm{P}}$ \\
\hline and similarly for reciprocal dams. \\
\hline Method III & \\
\hline
\end{tabular}

Avg. of 3-breed crosses - Avg. of 3-breed crosses

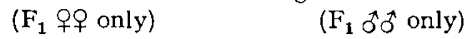

\begin{tabular}{c|c} 
Epistatic recombination effects $\left(r^{\mathrm{I}}\right)$ \\
\hline $1 / 2[(\mathrm{AB}) \mathrm{C}+(\mathrm{BA}) \mathrm{C}-\mathrm{AC}-\mathrm{BC}]$ & $h_{\mathrm{AB}}+1 / 4 r_{\mathrm{BA}}^{\mathrm{I}}$ \\
$1 / 2[(\mathrm{AC}) \mathrm{B}+(\mathrm{CA}) \mathrm{B}-\mathrm{AB}-\mathrm{CB}]$ & $h_{\mathrm{AC}}^{\mathrm{P}}+1 / 4 r_{\mathrm{AC}}^{\mathrm{I}}$ \\
$1 / 2[(\mathrm{BC}) \mathrm{A}+(\mathrm{CB}) \mathrm{A}-\mathrm{BA}-\mathrm{CA}]$ & $h_{\mathrm{BC}}^{\mathrm{F}}+1 / 4 r_{\mathrm{BC}}^{\mathrm{I}}$ \\
\hline
\end{tabular}

(1) The left most letter always represents the sire breed.

If only three breeds were involved, method III could not provide specific estimates of $h^{\mathrm{M}}$ for each kind of crossbred dam and method II should be the choice if unbiased estimates were desired. However, if four breeds were involved in the production of 3 -breed crosses it should be possible to obtain specific estimates of $h \mathrm{M}$, for example.

$$
\begin{aligned}
h_{\mathrm{AB}}^{\mathrm{M}}=\frac{1}{2}[\mathrm{C}(\mathrm{AB})+(\mathrm{AC}+\mathrm{BC}) / 2-(\mathrm{AB}) \mathrm{C}-(\mathrm{CA}+\mathrm{CB}) / 2 \\
\quad+\mathrm{D}(\mathrm{AB})+(\mathrm{AD}+\mathrm{BD}) / 2-(\mathrm{AB}) \mathrm{D}-(\mathrm{DA}+\mathrm{DB}) / 2]
\end{aligned}
$$


where $D$ represents the fourth breed. For this comparison to be true one must further assume that there is no interaction between the genotype of the offspring $(\mathrm{C}(\mathrm{AB}), \mathrm{D}(\mathrm{AB}))$ and that of the crossbred dam (AB). This is an extension of method II utilizing information on both possible 3-breed crosses.

The various comparisons listed in table $\mathbf{I}$ should be applicable to reproductive traits, such as litter size at various ages, for estimating $h$ 우 and $h \sigma^{*}$.

Reçu pour publication en août 1973.

\section{RÉSUMÉ}

\section{A PROPOS DES MÉTHODES D'ESTIMATION DE L'HÉTÉROSIS MATERNEL ET DES EFFETS DE RECOMBINAISON DANS UN SYSTÈME DONNÉ DE CROISEMENTS A TROIS RACES}

Cette note est une extension de l'article de Dickerson 1969). Trois méthodes sont comparées pour estimer l'hétérosis maternel à partir d'un plan systématique decroisements entre trois races. Les sources possibles de biais sont considérées; la méthode II fournit l'estimation la moins biaisée de l'hétérosis maternel. Par exemple :

$$
h_{\mathrm{AB}}^{\mathrm{M}}=\mathrm{C}(\mathrm{AB})+(\mathrm{AC}+\mathrm{BC}) / 2-(\mathrm{AB}) \mathrm{C}-(\mathrm{CA}+\mathrm{CB}) / 2 .
$$

On indique par ailleurs que les mêmes données pourraient être utilisées pour estimer les effets de recombinaison.

\section{REFERENCES}

Dickerson G. E., 1969. Experimental approaches in utilising breed resources. Anim. breed. Abstr., 37, I9I-202.

Dickerson G. E., 1973. (Personal Communication). 